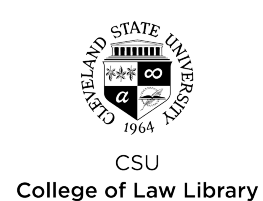

Cleveland State University

College of Law Library

\title{
EngagedScholarship@CSU
}

\section{PPACA and Public Health: Creating a Framework to Focus on Prevention and Wellness and Improve the Public's Health}

Gwendolyn R. Majette

Cleveland State University, g.majette@csuohio.edu

Follow this and additional works at: https://engagedscholarship.csuohio.edu/fac_articles

Part of the Health Law and Policy Commons

How does access to this work benefit you? Let us know!

Original Citation

Gwendolyn Majette, PPACA and Public Health: Creating a Framework to Focus on Prevention and Wellness and Improve the Public's Health 39 Journal of Law, Medicine \& Ethics 366 (2011)

This Article is brought to you for free and open access by the Faculty Scholarship at EngagedScholarship@CSU. It has been accepted for inclusion in Law Faculty Articles and Essays by an authorized administrator of EngagedScholarship@CSU. For more information, please contact research.services@law.csuohio.edu. 


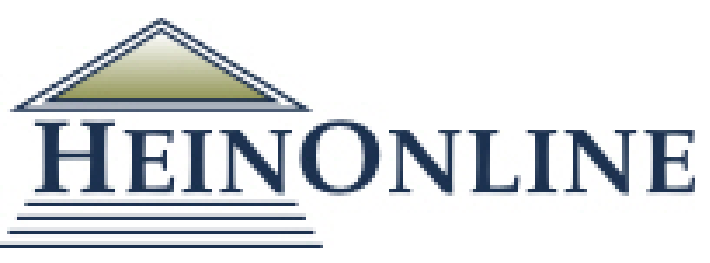

Content downloaded/printed from

HeinOnline

Thu Oct 10 11:25:19 2019

Citations:

Bluebook 20th ed.

Gwendolyn Roberts Majette, PPACA and Public Health: Creating a Framework to Focus on Prevention and Wellness and Improve the Public's Health, 39 J.L. Med. \& Ethics 366 (2011).

ALWD 6th ed.

Gwendolyn Roberts Majette, PPACA and Public Health: Creating a Framework to Focus on Prevention and Wellness and Improve the Public's Health, 39 J.L. Med. \& Ethics 366 (2011).

APA 6th ed.

Majette, G. (2011). Ppaca and public health: Creating framework to focus on prevention and wellness and improve the public's health. Journal of Law, Medicine Ethics, 39(3), 366-379.

Chicago 7th ed.

Gwendolyn Roberts Majette, "PPACA and Public Health: Creating a Framework to Focus on Prevention and Wellness and Improve the Public's Health," Journal of Law, Medicine \& Ethics 39, no. 3 (Fall 2011): 366-379

McGill Guide 9th ed.

Gwendolyn Roberts Majette, "PPACA and Public Health: Creating a Framework to Focus on Prevention and Wellness and Improve the Public's Health" (2011) 39:3 JL Med \& Ethics 366.

MLA 8th ed.

Majette, Gwendolyn Roberts. "PPACA and Public Health: Creating a Framework to Focus on Prevention and Wellness and Improve the Public's Health." Journal of Law, Medicine \& Ethics, vol. 39, no. 3, Fall 2011, p. 366-379. HeinOnline.

OSCOLA 4th ed.

Gwendolyn Roberts Majette, 'PPACA and Public Health: Creating a Framework to Focus on Prevention and Wellness and Improve the Public's Health' (2011) $39 \mathrm{JL}$ Med \& Ethics 366

Provided by:

Cleveland-Marshall College of Law Library

-- Your use of this HeinOnline PDF indicates your acceptance of HeinOnline's Terms and Conditions of the license agreement available at https://heinonline.org/HOL/License

-- The search text of this PDF is generated from uncorrected OCR text.

-- To obtain permission to use this article beyond the scope of your license, please use: Copyright Information

Use QR Code reader to send PDF to your smartphone or tablet device 


\section{PPACA and} Public Health: Creating a Framework to Focus on Prevention and Wellness and Improve the Public's Health

Gwendolyn Roberts Majette

\section{Introduction}

On March 23, 2010, President Obama signed the Patient Protection and Affordable Care Act (PPACA), ${ }^{\mathrm{I}}$ a major piece of health care reform legislation. This comprehensive legislation includes provisions that focus on prevention, wellness, and public health. Some, including authors in this symposium, question whether Congress considered public health, prevention, and wellness issues as mere afterthoughts in the creation of PPACA. As this article amply demonstrates, they did not.

This article documents the extent of congressional consideration on public health issues based on personal experience working on the framework for health care reform - specifically, my experience as a Fellow for a member of the Health Subcommittee of the Senate Finance Committee from 2008-2009. ${ }^{2}$ I also include a review of congressional activity in the United States House of Representatives. Analysis of the congressional meetings and hearings reveals that Congress had a deep understanding about the critical need to reform the U.S. public health and prevention system. The article illustrates how PPACA will have a positive impact on public health by examining the infrastructure that Congress designed to focus on prevention and wellness, with a particular emphasis on the National Prevention, Health Promotion and Public Health Council, the National Prevention, Health Promotion, Public Health, and Integrative Health Care Strategy, and the Prevention and Public Health Fund. The Council, strategy, and fund are especially important because they reflect compliance with some of the Institute of Medicine's recommendations to improve public health in the United States, as well as international health and human rights norms that protect the right to health.

\section{What Is Public Health and Why the U.S. Public Health and Prevention System Needs to Be Reformed}

The Institute of Medicine (IOM) defines public health as "what we as a society do collectively to assure the conditions for people to be healthy."3 Unfortunately, the United States spends trillions of dollars on health

Gwendolyn Roberts Majette, J.D., LL.M., is an Assistant Professor of Law at the Center for Health Law and Policy at Cleveland-Marshall College of Law. Professor Majette has Capitol Hill experience. She was a Fellow with the Health Subcommittee of the Ways and Means Committee of the United States House of Representatives and with Senator Debbie Stabenow, a member of the Health Subcommittee of the Senate Finance Committee. Ms. Majette received her LL.M. in Global Health Law from the Georgetown Law Center, her J.D. from George Washington University School of Law, and her B.B.A. from Emory University. 
care each year, yet the incidence of chronic and preventable diseases is escalating. ${ }^{4}$ In fact, the United States has the highest per capita and total health spending among industrialized nations, ${ }^{5}$ yet ranks very low on preventable mortality and infant mortality indicators. ${ }^{6}$

Experts agree that the public health system ${ }^{7}$ in the United States needs to be improved. The public health system is underfunded, and there is insufficient collaboration on public health activities at the federal and the federal-state level. ${ }^{8}$ The public health system is also siloed from the health care delivery system. ${ }^{9}$ Additional research is needed to identify effective public health practices. ${ }^{10}$ Other decision making and the measure of success; and (6) Enhance and facilitate communication within the public health system. ${ }^{15}$

More recently, in 2010, the Institute of Medicine noted that significant improvements in the health of the U.S. population would require an "ecologic, populationbased approach to health improvement."16 Thus, it would be insufficient to simply focus on improving the efficiency and effectiveness of the clinical-care delivery system. Instead, the IOM recommended that increased attention focus on preventing disease and promoting health. ${ }^{17}$

On March 23, 2010, President Obama signed the Patient Protection and Affordable Care Act (PPACA), a major piece of health care reform legislation. This comprehensive legislation includes provisions that focus on prevention, wellness, and public health. Some, including authors in this symposium, question whether Congress considered public health, prevention, and wellness issues as mere afterthoughts in the creation of PPACA. As this article amply demonstrates, they did not.

major problems include the lack of transparent and easily understandable information about health, ${ }^{11}$ "vulnerable and outdated information systems," a poorly trained public health workforce, "antiquated laboratory capacity," "a lack of real time surveillance and epidemiological systems," "ineffective communications networks, incomplete domestic preparedness and emergency response capabilities, and communities without access to essential public health service." ${ }^{12}$ In 2002 , the IOM issued a report, The Future of the Public's Health in the 21st Century, which analyzed the systems and entities that protect the public's health. The IOM made six broad recommendations ${ }^{13}$ on how to improve the public health system and better protect the collective health of Americans:

(1) Adopt[] a population health approach that considers the multiple determinants of health;

(2) Strengthen[ ] the governmental public health infrastructure; (3) Build[] intersectoral partnerships that draw on the perspectives and resources of diverse communities and engage them in health action; (4) Develop[] systems of accountability to assure the quality and availability of public health services; ${ }^{14}$ (5) Make[] evidence the foundation of
III. The Health Care Reform Debate: Initiatives of the United States Congress Designed to Reform the U.S. Public Health and Prevention System and Focus on Prevention and Health Promotion

Due to the various problems in public health, Congress addressed these issues as they began their discussion on a framework for health care reform legislation.

\section{A. The Senate}

1. FRAMEWORK FOR HEALTH CARE REFORM

The Health Education Labor and Pension Committee (HELP) and the Health Subcommittee of the Senate Finance Committee, the two Senate committees with jurisdiction over health, and health reform in particular, viewed public health as a significant issue. As a Fellow, I was a part of the Health Subcommittee of the Senate Finance Committee conversations laying the framework for the health care reform legislation. Our framework was three-fold: (1) coverage, (2) delivery system reform, and (3) prevention, wellness, and public health. Staffers for both the Health Subcommittee of the Senate Finance Committee and the HELP Committee attended regular meetings on these topics.

In thinking about public health, some of our discussions included speaking with organizations invested 
in prevention and wellness, such as the U.S. Preventive Services Task Force, the Task Force on Community Preventive Services, Trust for America's Health, and Partnership for Prevention. Representatives from the U.S. Preventive Services Task Force and the Task Force on Community Preventive Services made a joint presentation to the HELP and Senate Finance Health Subcommittee staffers entitled, "What Works to Promote Health? Evidence-Based Recommendations from the Task Forces on Clinical and Community Preventive Services." 18 Trust for America's Health presented, "Prevention for a Healthier America: Investments in Disease Prevention Yield Significant Savings, Stronger Communities."19

The HELP and Senate Finance Health Subcommittee staffers also discussed existing bills targeted to public health issues. For example, we discussed two bills by Senator Tom Harkin, a long-time proponent of prevention and wellness. The first bill, Healthy Lifestyles and Prevention Act of 2007 was a comprehensive piece of legislation that presented Senator Harkin's vision on how to create a wellness-focused society in the U.S. ${ }^{20}$ The second, more targeted Harkin bill was the Healthy Workforce Act of $2007 .{ }^{21}$ This bill encouraged employers to invest in comprehensive wellness programs by providing a tax credit to support small business efforts to create healthier work environments. ${ }^{22}$ Additionally, we discussed Senator Hillary Rodham Clinton's bill, 21st Century Wellness Trust Act (Wellness Trust). ${ }^{23}$ The Wellness Trust was designed to create a prevention system "that assures access to clinical and community level prevention services that improve health, quality of life, and reduce healthcare costs." ${ }^{24}$ Under the bill, a presidentially appointed board would create an evidence-based blueprint that would set national prevention priorities and allocate resources to achieve those priorities..$^{25}$ The Wellness Trust would also help build a wellness infrastructure by building a "central source of prevention information," creating an electronic prevention record, and helping to train and credential prevention workers. ${ }^{26}$ The Trust would be the primary payer for prevention services and be funded by pooling the resources from existing federal programs targeted to prevention coupled with an annual assessment on private insurance companies. ${ }^{27}$

The solutions discussed among the HELP and Health Subcommittee of Senate Finance staffers to improve prevention, wellness, and public health were ultimately included in various forms of health care reform proposals, bills, and enacted legislation. For example, Senator Max Baucus, Chairman of the Senate Finance Committee, issued one of the early major proposals for comprehensive health care reform. On
November 12, 2008, Senator Baucus, published a paper entitled, "Call to Action: Health Reform 2009," detailing his vision for health care reform. ${ }^{28}$ Baucus' paper included provisions addressing public health and prevention issues. The topies included: "Strengthening Public Programs, Focusing on Prevention and Wellness, Addressing Health Disparities, Strengthening the Role of Primary Care, and Chronic Care Management." 29 Many of the substantive provisions were discussed in joint HELP-Health Subcommittee of Senate Finance meetings.

Call to Action also included provisions outlining recommendations for health insurance and prevention. For example, one recommendation focused on elimination of copayments for prevention services in the Medicare, Medicaid, and Children's Health Insurance Program (CHIP) programs. ${ }^{30}$ Moreover, certain prevention services were included in the minimum level of health benefits that private insurance companies would offer in the health insurance exchanges. ${ }^{31}$ For the uninsured, they would receive a "Right Choices Card." The card would give them temporary, limited access to proven prevention measures such as a health risk assessment, physical exam, immunizations, cancer screening, and community resources for smoking cessation and nutrition counseling. ${ }^{32}$ Small employers would receive a tax credit for the creation of comprehensive corporate wellness programs, and thus be incentivized to provide such programs. ${ }^{33}$

Under Baucus' proposal, Congress would provide grants to the states and communities to help target prevention and wellness initiatives at the local level. ${ }^{34}$ To help shift the country to focus more on prevention and wellness, the proposal recognized the need for creating a coordinated, national strategy to reduce chronic disease and obesity. Part of the coordinated strategy included creation of a Wellness Trust. ${ }^{35}$ Call to Action also recommended commissioning a study to identify and propose solutions that would better coordinate federal programs designed to address chronic diseases and obesity. ${ }^{36}$

In 2008, the original leadership structure of the HELP Committee reinforced the three-fold health reform framework. Senator Edward M. ("Ted") Kennedy, Chairman of the HELP committee assigned a senator to lead legislative health care reform efforts, including hearings, on each of the three areas: (1) coverage, (2) quality, an important aspect of delivery system reform, and (3) prevention, wellness, and public health. ${ }^{37}$ Senator Tom Harkin was assigned prevention, wellness, and public health - issues that he championed for over a decade. Senator Harkin had a three-prong approach to reform the U.S. health care system to create a "wellness society." It included initia- 
tives to infuse public health, prevention, and wellness at the federal, clinical, and community health levels. ${ }^{38}$

Similarly, in the first quarter of 2009, the Health Subcommittee of Senate Finance divided prevention topics among at least four senators. One senator was given the lead to work on chronic care management, another focused on disparities, and two senators were tasked with leading legislative initiatives on prevention and wellness. on wellness. ${ }^{41}$ Wright's testimony focused on describing how the HHS was "building a prevention evidence base and infrastructure." 42 The foundation of the prevention infrastructure is the Healthy People project, a "comprehensive set of national ten-year health promotion and disease prevention objectives aimed at improving the health of all Americans." ${ }^{* 3}$ Secretary Wright also highlighted the department's attempts to address how social determinants - physical and social environment, individual behavior, genetics, and health care delivery affect health. ${ }^{44}$

He further noted how the prevention evidence base has been used to develop guidelines regarding physical activity, nutrition, clinical prevention, community prevention, and communication..$^{45}$ Additionally, while Secretary Wright described the activities of many departments within HHS working on prevention ${ }^{46}$ the basic purpose of two departments is worth highlighting - the Centers for Disease Control and Prevention (CDC) and the National Institute

2. HEARINGS ON PREVENTION IN PREPARATION FOR HEALTH CARE REFORM LEGISLATION

Congress held many hearings on the topic of health care reform from 2008 until passage of the Patient Protection and Affordable Care Act on March 23, 2010. In the Senate, at least 40 hearings were held on health care reform and at least 53 hearings were held in the House of Representatives. ${ }^{39}$ Congress also held many hearings on public health topics generally.

On December 10, 2008, Senator Harkin, the HELP senator charged with leading initiatives focusing on prevention, public health, and wellness, chaired a hearing entitled "Prevention and Public Health: The Key to Transforming our Sickcare System." Three key witnesses included the following: Dr. Donald Wright, Principal Deputy Assistant Secretary for Health, U.S. Department of Health and Human Services (HHS); Dr. Jeffrey Levi, Executive Director, Trust for America's Health; and Dr. Kenneth E. Thorpe, Professor, Department of Health Policy and Management, Rollins School of Public Health at Emory University. ${ }^{40}$ These witnesses provided the perspectives of the leading federal administrative agency on health matters, a think tank, and the public health academic community.

\section{SECRETARY DONALD WRIGHT}

Under Secretary Wright's vision of a reformed health care system, care is person centered; clinical care and community care is integrated; disease care is provided to the sick; and prevention is emphasized by focusing for Health (NIH). According to Secretary Wright, the $\mathrm{CDC}$ focuses on protecting health through initiatives targeted to promotion, prevention, and preparedness. NIH focuses on research in prevention, which includes research on nutrition, physical activity, and obesity. ${ }^{47}$

\section{DR. JEFFREY LEVI}

Consistent with his October 2008 presentation to the HELP and Senate Finance Health Subcommittee staffers, Dr. Jeffrey Levi identified several key areas of the U.S. health care system that need to be reformed to focus on prevention. ${ }^{48}$ First, Dr. Levi recommended that investments be made in clinical and communitybased prevention to make insurance coverage more cost-effective. ${ }^{49}$ Dr. Levi also discussed the need for a national prevention plan..$^{50} \mathrm{He}$ asserted that such a plan was necessary to raise the importance of prevention and public health and maximize the effectiveness of existing federal programs. He testified that federal programs would become more effective if the prevention activities were coordinated and based on national priorities. ${ }^{51}$ Finally, Dr. Levi discussed the need to ensure that there is "stable and reliable funding for core public health functions, and clinical and preventive services."52

PROFESSOR KENNETH E. THORPE

Professor Thorpe provided insight on how investments in prevention might reduce health care costs. He testified that the chief driver of the rising health care costs 
in the United States is the increase in chronic diseases. ${ }^{53} \mathrm{He}$ further noted that investments in evidencebased community interventions could reduce cost. ${ }^{54} \mathrm{He}$ encouraged the use of approaches that reflected best practices for prevention and public health initiatives. For example, he made the following recommendations: (1) allow for universal access to prevention and wellness services; ${ }^{55}$ (2) use community challenge grants to support evidence-based community prevention; ${ }^{56}$ (3) support evidence-based workplace wellness programs; ${ }^{57}$ and (4) integrate clinical preventive care using the medical home concept for larger medical groups and community health teams for smaller medical groups. ${ }^{58}$ Professor Thorpe asserted that the link to community health teams would enable physicians to provide care through "care coordinators, nurse practitioners, social and mental health workers, and outreach workers." 59

Two months later, the HELP Committee held two additional hearings on prevention and wellness. On February 23, 2009, the committee held a hearing entitled, "Examining Principles of Integrative Health, Focusing on a Path to Healthcare Reform" and on February 26, 2009, the hearing was entitled, "Integrative Care: A Pathway to a Healthier Nation." These hearings focused on "(1) the need to transform the U.S. health care system to focus on health and wellness; (2) the need for executive level leadership to develop and coordinate federal policy on integrative healthcare; (3) the definition of integrative healthcare; (4) initiatives by famous integrative medicine physicians like Dr. Mehmet C. Oz and Dr. Andy Weil on steps individuals can take to improve their health through healthy living;" 60 and (5) the need to support workplace wellness programs as a means to improve employee health and reduce chronic diseases. ${ }^{61}$ At least one witness testified that focusing on preventive measures would reduce health care costs by billions of dollars. ${ }^{62}$

\section{PRELIMINARY LEGISLATIVE PROPOSALS AND THE EMPHASIS ON PREVENTION, WELLNESS, AND PUBLIC HEALTH}

In the Senate, both the HELP and Senate Finance Committees passed bills containing provisions that emphasized prevention, wellness, and public health. On July 15, 2009, the HELP Committee passed the Affordable Health Choices Act. ${ }^{63}$ Title III of the Act entitled, "Improving the Health of the American People," addresses prevention and public health. Specifically, the subtitles demonstrate a focus on the following areas: Modernizing Disease Prevention and the Public Health Systems (Subtitle A); Increasing Access to Clinical Preventive Services (Subtitle B); Creating Healthier Communities (Subtitle C); and Support for Prevention and Public Health Innovation (Subtitle
D). ${ }^{64}$ In addition, two key provisions focus on modernizing disease prevention and the public health system by creating the National Prevention, Health Promotion and Public Health Council, and the Prevention and Public Health Fund. ${ }^{65}$

Similarly, the Senate Finance bill - America's Healthy Futures Act - also contains provisions focusing on prevention and wellness. For example, Title II focuses on promoting disease prevention and wellness in the Medicare, Medicaid, and CHIP programs. ${ }^{66}$ In the Medicare program, for example, beneficiaries would be entitled to an annual wellness visit that would include a health risk assessment and a personalized prevention plan. ${ }^{67}$ The proposal also requested a General Accounting Office study on access to immunizations for Medicare beneficiaries. ${ }^{68}$ With respect to the Medicaid program, the proposal provided incentives for states to improve coverage of and access to recommended preventive services and immunizations. ${ }^{69} \mathrm{It}$ included funds to develop a grant program for states to implement incentives for healthy lifestyles..$^{70} \mathrm{It}$ also included a $\$ 25$ million appropriation to fund a childhood obesity demonstration project. ${ }^{71}$

\section{B. The House}

1. HEARINGS ON HEALTH CARE REFORM IN THE UNITED STATES HOUSE OF REPRESENTATIVES The need to implement the IOM's 2002 recommendations $^{72}$ to improve the health of Americans was also reflected in the recent health care reform conversation that occurred in the United States House of Representatives. For example, in a 2009 hearing of the Subcommittee on Health for the Committee on Energy and Commerce, various experts testified about approaching health reform with a public health perspective. Some of the key experts included the Acting Director of the CDC, the Director of the Task Force on Community Preventive Services and Chair of the Secretary's Advisory Committee on National Health Promotion and Disease Prevention Objectives for 2020, and a former Surgeon General of the United States.

\section{DR. RICHARD BESSER}

According to Dr. Besser, Acting Director of the CDC,

for Americans to truly be healthier, they must not only have access to treatment once sick, but they should also receive recommended screenings to detect the risk of disease early; have access to evidence-based interventions to prevent disease and injury before they occur; be supported by care systems that minimize the progression of disease once it occurs; and live, work and play in environments that promote healthy choices and behaviors. ${ }^{73}$ 
Dr. Besser stressed the need for creating a "comprehensive system that integrates health care delivery and prevention." ${ }^{74} \mathrm{He}$ stated that the $\mathrm{CDC}$ and its public health partners were working to create connections between patients and community resources; between doctors and nurses; and between clinicians and public health officials. ${ }^{75}$ Adoption of a broad national prevention agenda would improve population health, reduce health disparities, and reduce health costs. ${ }^{76} \mathrm{Dr}$. Besser advocated for a National Prevention Agenda that would include (1) equipping individuals with "the tools and support to enable them to take responsibility for their own health"; (2) the use of evidence-based prevention and wellness initiatives; (3) "rigorous tracking, monitoring and evaluations [to] measure performance and ensure accountability"; (4) a commitment to develop more effective relationships with state and local health agencies and the public health infrastructure to improve health outcomes; (5) "tailored interventions to reduce health disparities" and improve health outcome for high-risk populations; and (6) the use of policy to improve health.77

Dr. Besser highlighted previous initiatives designed to focus on prevention, such as the $\$ 1$ billion dollar Prevention and Wellness Fund created under the America Recovery and Reinvestment Act..$^{78}$ Part of that funding went to increase access for immunizations; reduce health care associated infections; and implement evidence-based clinical and communitybased prevention and wellness strategies that target chronic disease. ${ }^{79}$ According to Dr. Besser, the CDC is engaged in proven prevention initiatives including: access to immunizations; tobacco prevention and cessation, especially among adolescents; obesity prevention through the "Healthy Communities" program; initiatives to address health care disparities; behavioral approaches to HIV prevention; health care associated infections related to central lines; and prevention of falls among older adults. ${ }^{80}$ The CDC is also working to collect data that permits monitoring of the changes in health after introduction of prevention or health care interventions for accountability purposes. ${ }^{81}$

\section{DR. JONATHAN FIELDING}

Another key witness in the 2009 hearings was Dr. Jonathan Fielding, the Director of the Task Force on Community Preventive Services (TFCPS) and Chair of the Secretary's Advisory Committee on National Health Promotion and Disease Prevention Objectives for 2020. Dr. Fielding discussed the need for reform measures to expand scientific review of communitybased prevention and dissemination of that scientific information. He reiterated his belief that the "greatest opportunities to improve the country's health lies in population-oriented policies and programs." ${ }^{{ }^{2}}$ Dr. Fielding also discussed the need for additional funding to enable the TFCPS to conduct further reviews of the effectiveness of community-based interventions. ${ }^{83}$ There is a significant gap between the number of reviews completed and the identified high-priority reviews that need to be completed. ${ }^{84}$ Additionally, he asserted that the Community Prevention Guide needed wider dissemination so that it would be used..$^{85}$ $\mathrm{He}$ found that there was little awareness of the guide, and that most governmental public health agencies had not used it as part of their standard practice.

Additionally, Dr. Fielding recommended increased research to understand which combination of interventions is most effective. ${ }^{86}$ Finally, he recommended creating a link between the recommendations of the Community Prevention Guide and the Healthy People 2020 objectives so the priorities of each are influenced by the other. ${ }^{87}$

\section{JEFFREY LEVI}

Jeffrey Levi, Ph.D., Executive Director of Trust for America's Health, testified consistent with his December 2008 testimony before the Senate HELP committee. ${ }^{88}$ He noted that the public health system was structurally weak because of its underfunding. For example, some health departments did not have enough resources to carry out core disease prevention programs. ${ }^{89}$ Moreover, he found that the economic crisis compounded the underfunding. Since the economic crisis, federal agencies have reduced funding, and state capacity to maintain public health investments has been significantly reduced. ${ }^{90} \mathrm{He}$ reiterated the need for a reliable, stable funding stream for public health programs and services. In order to ensure the effective use of funding, Dr. Levi reiterated the importance of selecting evidence-based, cost-effective interventions. Finally, he urged creation of a Public Health Research Institute to further build the evidence base for prevention and to develop and disseminate best practices for public health systems and services. ${ }^{91}$

\section{DR. DAVID SATCHER}

The former Surgeon General of the United States, Dr. David Satcher, M.D., Ph.D., provided a detailed analysis of how social determinants impact population health. He also highlighted the need to adopt a public health approach to health care reform to appropriately address the social determinants. The four major determinants of health include: (1) access to quality health care; (2) a person's biological or genetic background; (3) physical and social environment; and (4) lifestyle or human behavior. ${ }^{92}$ However, these major determinants are "overrid[den] by major social issues such as poverty, income and working conditions." ${ }^{33}$ 
Dr. Satcher testified that the public health approach includes four steps: "( 1$)$ Define the problem, including its magnitude, nature, and distribution; (2) Determine the cause of the problem and the risk factor(s) associated with it; (3) [Identify solutions to] prevent[] or ameliorate[] the problem; and (4) Translate solutions to the population more broadly." 94 With respect to the U.S. health care system, it is well accepted that there is an adverse impact of having an out-of-balance health care system that fails to appropriately address health promotion, disease prevention, early detection, and tored over the phone. ${ }^{100}$ Case managers also monitor the care of patients admitted to the hospital or rehabilitation facilities. ${ }^{101}$

According to Dr. Spivak, the IPA physicians also participate with a third-party payor in a wellness initiative entitled "Care Alerts." This program compares claims data to clinical guidelines to identify gaps in care, medication, quality, or patient safety. Comparison with 1,500 evidence-based clinical rules provides an opportunity to "optimize patient care; ensure compliance with recommended treatments, and deliver[]

\section{PPACA contains many provisions that address public health and prevention. A large number of the provisions are included in Title IV on Prevention of Chronic Disease and Improving Public Health. This title includes a broad array of topics, many of which were addressed in congressional hearings or one of the comprehensive pieces of health care reform legislation that passed out of the congressional committees with jurisdiction over health.}

universal access to care. In 2009, the United States spent $95 \%$ of the health budget on treating disease and $3 \%$ on population-based prevention. ${ }^{95}$ Dr. Satcher testified that the United States needed to commit more resources to "promoting health in the home, workplace, school, and community." 96 Thus, investments should be made to address the "social determinants of health or the conditions in which people are born, grow, learn, develop, and age." ${ }^{97}$ He noted that there are various health promotion and prevention mechanisms that can be used, such as encouraging wellness programs in the workplace, supporting physical education and good nutrition in schools, or supporting "faith-based programs to reach communities that would otherwise fall through the cracks." ${ }^{98}$

\section{BARBARA SPIVAK}

Dr. Barbara Spivak, M.D., President, Mount Auburn Cambridge Independent Physician Association (IPA), explained the impact of practicing physicians on public health. Through her position as president of a large IPA with over 500 physicians, Dr. Spivak provided insight into the role that physicians play in using coordinated care to manage chronic diseases and in clinical prevention and wellness. ${ }^{99}$ She asserted that the IPA physicians evaluate the health needs of patients and work with case managers to help the patients manage their illness. Those with chronic conditions are categorized according to compliance needs: those needing in-person visits and those who can be moni- preventive services."102 Once a gap is found, it is addressed through an immediate call to the physician if there is an emergent issue (i.e., drug interaction) or a letter to the physician identifying the gap, followed by a letter to the patient. ${ }^{103}$

Subsequently, in May 2009, the Health Subcommittee of Ways and Means held a hearing with HHS Secretary Kathleen Sebelius. During this hearing Secretary Sebelius emphasized the need to invest in prevention and wellness. She stated that "[i]t's time to make preventing illness and disease the foundation of our health care system."104

2. HOUSE PRELIMINARY LEGISLATIVE PROPOSALS AND THE EMPHASIS ON PREVENTION, WELLNESS, AND PUBLIC HEALTH

In the House of Representatives, the first comprehensive health care reform bill was America's Affordable Health Choices Act of 2009 introduced on July 14, 2009. ${ }^{105}$ The House Committees on Ways and Means, Energy and Commerce, and Education and Labor jointly developed the bill. The bill included provisions to ensure that Americans had access to quality medical services and helped to strengthen the public health system to keep people well and safe in their communities. ${ }^{106}$ Title III - Prevention and Wellness of Division $\mathrm{C}$ of the Act had 5 subtitles that focused on prevention and wellness. The five subtitles include (1) Prevention and Wellness Trust (Subtitle A); (2) National Prevention and Wellness Strategy (Subtitle B); (3) Prevention 
Task Forces (Subtitle C); (4) Prevention and Wellness Research (Subtitle D); and (5) Delivery of Community Preventive and Wellness Services (Subtitle E). ${ }^{107}$

\section{PPACA and Public Health and Prevention Generally}

PPACA contains many provisions that address public health and prevention. ${ }^{108} \mathrm{~A}$ large number of the provisions are included in Title IV on Prevention of Chronic Disease and Improving Public Health. This title includes a broad array of topics, many of which were addressed in congressional hearings or one of the comprehensive pieces of health care reform legislation that passed out of the congressional committees with jurisdiction over health. For example, in Subtitle B - Increasing Access to Clinical Preventive Services, provisions are made to expand school-based health centers; remove cost-sharing for Medicare preventive services; provide a personalized prevention plan based on a comprehensive health risk assessment under Medicare; provide coverage for comprehensive tobacco cessation services for pregnant women under Medicaid; and provide grants to states to provide incentives for Medicaid beneficiaries to adopt healthy lifestyles. ${ }^{109}$ Subtitle C - Creating Healthier Communities includes community transformation grants; a requirement that chain restaurants provide nutrition labeling for standard menu items; and a requirement that employers of a certain size provide a clean private room and break time for nursing mothers. ${ }^{110}$ In Subtitle D - Support for Prevention and Public Health Innovation, there is a provision requiring the $\mathrm{CDC}$ to provide technical assistance to employers on the operation and evaluation of their workplace wellness plan; a provision providing appropriations for a childhood obesity demonstration project; and a provision to advance the research and treatment for pain care management. ${ }^{111}$

\section{PPACA and the New National Prevention, Health Promotion and Public Health Council, Strategy, and Fund}

A. PPACA - Creating a National Approach to Focus on Prevention, Wellness, and Health Promotion

PPACA creates a national approach to focus on prevention and public health through creation of a council, a strategy, and a prevention fund that addresses these topics. PPACA establishes the National Prevention, Health Promotion and Public Health Council (Council) to provide leadership on and coordinate public health activities by federal agencies. ${ }^{112}$ Pursuant to PPACA, President Obama issued an executive order establishing the Council and appointed the Surgeon General as Chair. ${ }^{133}$ The other members are composed of 12 identified executive level leaders in federal agen- cies and other federal agencies that the Surgeon General deems appropriate. ${ }^{114}$

In addition to providing federal leadership, the Council has two other important duties that are broadly defined by PPACA. First, the Council must create a National Prevention, Health Promotion, Public Health, and Integrative Health Care Strategy. ${ }^{115}$ This strategy will focus on identifying effective means ${ }^{116}$ to "improve the health status of Americans and reduce the incidence of preventable illness and disability in the United States."117 According to the Council's first annual report, creation of the strategy will be guided by eight principles. They include the following: (1) "prioritiz[ing] prevention and wellness"; (2) "establish[ing] a cohesive federal response"; (3) "focus[ing] on preventing the leading causes of death and their underlying factors"; high-impact interventions"; (5) "promot[ing] highvalue preventive care practices"; (6) "promoting health equity"; 119 (7) "promot[ing] alignment between the public and private sector"; and (8) "ensur[ing] accountability."120 The strategy will build upon existing federal programs such as Healthy People 2020.121 The first strategy was due no later than March 23, 2011, and it should be revised periodically as needed. ${ }^{122}$

On April 4, 2011, the Council released the draft Framework for the National Prevention Strategy. The vision for the strategy is "working together to improve the health and quality of life for individuals, families, and communities by moving the nation from a focus on sickness and disease to one based on prevention and wellness." 123 The goal of the strategy is to "increase the number of Americans who are healthy at age 85."124 Based on the framework the strategy has four basic pillars: (1) "Create, sustain, and recognize communities that support prevention and wellness"; ${ }^{125}$ (2) "Connect prevention-focused health care and community efforts to increase preventive services"; 126 (3) "Empower and educate individuals to make healthy choices"; ${ }^{127}$ and (4) "Eliminate disparities in traditionally underserved populations to improve the quality of life for all Americans." 28 The framework creates two levels of priorities: one that focuses on systems and services integral to prevention ${ }^{129}$ and one that targets leading causes of death, i.e., "targeted priorities."130 The framework targets seven priorities: tobacco-free living, preventing alcohol and other drug abuse, healthy eating, active living, injury free living, mental and emotional wellbeing, and sexual health.

Under PPACA, the second important duty of the Council is to make "recommendations to the President and Congress concerning the most pressing health issues confronting the United States and changes in Federal policy to achieve national wellness, health 
promotion, and public health goals." ${ }^{131}$ An Advisory group composed of 25 non-federal, licensed health professionals will assist the Council with its various duties. ${ }^{132}$ The advisory group will focus on three key public health issues: (1) "lifestyle-based chronic disease prevention and management," (2) "integrative health care practices," and (3) "health promotion." 133

Each year the Council must provide a report to the president and Congress on the activities and efforts on prevention, health promotion, and public health, and the national progress toward those goals. ${ }^{134}$ The report must also identify the "national priorities on health promotion and disease prevention to address lifestyle behavior modification....and the prevention measures for the 5 leading disease killers in the United States."135 Additionally, the report should contain "science-based initiatives to achieve the measurable goals of Healthy People 2020 regarding nutrition, exercise, and smoking, and target[] the 5 leading disease killers in the United States." 136 Further, the report must include plans to ensure that all federal health programs and non-HHS programs are consistent with "sciencebased recommendations and guidelines developed by the Centers for Disease Control and Prevention."137

PPACA also addresses the need to provide a stable source of funding for public health and prevention initiatives in the United States through the creation of the Prevention and Public Health Fund. As such, \$15 billion dollars is authorized and appropriated over 10 years. The statute also provides for continuous funding to the trust in the amount of $\$ 2$ billion per year. ${ }^{138}$ The HHS Secretary's office administers the fund. ${ }^{139}$ According to PPACA, the purpose of the fund is "to provide for expanded and sustained national investment in prevention and public health programs and to improve health and help restrain the rate of growth in private and public sector health care costs." ${ }^{140}$

\section{B. Positive Impact of the Prevention Council, Strategy, and Fund on Prevention and Wellness Initiatives in the United States}

There are several reasons that the creation of the Council and the development of a national prevention strategy will positively impact the health of the U.S. population. First, they eliminate a fragmented approach to prevention and wellness by forcing the various federal government agencies to discuss and coordinate initiatives. This coordination is important with respect to health-related programs as well as regulations. Additionally, the composition of the Prevention Council helps to ensure that health will be considered in the policies of most federal government agencies. The council is chaired by the Surgeon General, charged with promoting the health of the nation, and includes heads of non-health agencies, for example, the Secretaries of Transportation, Education, and Agriculture.

Second, the Council and strategy are important because they do not merely establish goals and objectives but also provide a mechanism for developing an implementation plan to achieve the goals and objectives. However, the power of the Council to implement change is statutorily limited. ${ }^{141}$ The Council lacks the resources and authority to promulgate regulations, sub-regulatory guidance, or legislation. These actions remain within the purview of the executive agencies or Congress.

Third, the Council and strategy maximize limited financial federal resources by targeting those resources to identified health priority areas. Fourth, because the strategy must address prevention, management, and reduction of chronic diseases - the key cost driver to the increase in U.S. health care costs - the strategy should lower or at least better control the rising health care costs. ${ }^{142}$ Not only is there a financial benefit from the work of the Council, there is also a public health benefit: decreased rates of disease, disability, and illness.

Fifth, creation of a strategy puts the U.S. in compliance with international health and human rights norms, which require governments as part of their minimum core obligations to create a comprehensive plan to address the "health concerns of the entire population." 143 The Council's charge to not only create a plan but also make recommendations for implementing the strategy is consistent with these international norms. The prevention fund provides the necessary financial resources to the HHS Secretary to implement the plan. Creation of the prevention fund is also consistent with health and human rights norms that require countries to "identify resources available to attain the objectives [defined in the plan]," as well as identify "the most costeffective way [to use] the resources."144 Sixth, the Prevention Council plays a critical role in implementation through its advisory role to the President and Congress on the status of the health of the American population; the effectiveness of health prevention and promotion programs; and the changes that need to be made to federal policy "to achieve national wellness, health promotion, and public health goals." 145

Finally, consistent with the IOM 2002 public health recommendations ${ }^{146}$ and health and human rights norms, PPACA creates an accountability mechanism regarding the work of the Prevention Council and the use of the Prevention Fund. ${ }^{147}$ Every five years the Secretary of HHS and the Comptroller General are required to review the "effectiveness of programs, initiatives, and agencies" related to prevention and health promotion..$^{148}$ 


\section{Conclusion}

Prior to the passage of PPACA, the existing federal law on prevention primarily included (1) limited coverage of preventive medical services under Medicare and Medicaid; (2) grant funding for community-based research programs and disease prevention and health promotion programs; (3) support for review of scientific evidence governing clinical and community prevention initiatives; (4) dissemination of information such as the Guide to Clinical Preventive Services and the Guide to Community Preventive Services; and (5) regulation of employer wellness plans. ${ }^{149}$ However, there were two important gaps in the existing law. There was no comprehensive prevention and wellness statute and no spending statute targeted to prevention and wellness. ${ }^{150}$ PPACA fills both of those gaps.

At the beginning of the congressional health care reform conversation, the importance of the role of public health, prevention, and wellness was discussed. As early as fall 2008, Senate congressional staffers discussed these issues. Public health, prevention, and wellness were reflected in existing bills like Senator Tom Harkin's Healthy Lifestyles and Prevention America Act of 2007, a comprehensive piece of legislation that could be used as a guide for health reform initiatives. They were also reflected in early congressional proposals on health care reform from chairs of health committees such as Senator Max Baucus of the Senate Finance Committee. As the conversation on health care reform continued, congressional hearings were held in both chambers on public health, prevention, and wellness, and each comprehensive proposal from a committee with jurisdiction over health included titles and provisions on these topics.

Some of the most important public health, prevention, and wellness provisions in PPACA are the provisions creating the National Prevention, Health Promotion, and Public Health Council, strategy, and fund. These provisions create a framework to reform the U.S. health care system to focus on prevention and wellness and to improve the public health. The Council provides leadership and coordination at the federal level on these topics. Creation of a strategy means that high-impact priority areas will be identified to target our limited resources and that an evidencebased implementation plan will guide future efforts. The prevention fund provides desperately needed resources to make financial investments into public health, prevention, and wellness initiatives.

Moreover, the ideas reflected in the Council, strategy, and fund are consistent with the Institute of Medicine's broad recommendations on how to improve public health in the 21st century. Additionally, they are consistent with international health and human right norms that govern how countries should protect population health.

\section{Acknowledgements}

The author wishes to thank the congressional staffers who generously shared their experiences and insights about the health care reform process. She would like to extend her appreciation to her husband, Mario Majette, M.D., M.P.H., and attorneys Sandy Han and Tachunta Thomas for their willingness to review drafts of this article. She also wishes to thank the following individuals for their research assistance: members of the CM-Law library staff, especially Amy Burchfield and Beth Farrell, and her research assistant, Joshua D. DiYanni.

\section{References}

1. Patient Protection and Affordable Care Act, Pub. L. No. 111-148, 124 Stat. 573 (2010) (hereinafter cited at PPACA).

2. The author was a Fellow with Senator Debbie Stabenow, a member of the Health Subcommittee of the Senate Finance Committee.

3. See also Institute of Medicine, Committee for the Study of the Future of Public Health, The Future of Public Health (Washington, D.C.: National Academies of Science, 1988): at 19, available at <http://books.nap.edu/openbook.php?record_ id=1091\&page $=19>$ (last visited July 13, 2011).

4. In 2009 the total health expenditures amounted to $\$ 2.5$ trillion and in 2008, \$2.4 trillion. Centers for Medicare and Medicaid Services, National Health Expenditure Data, available at <https://www.cms.gov/NationalHealthExpendData/downloads/tables.pdf> (last visited June 21, 2011).

5. Organisation for Economic Co-operation and Development (OECD), Health at a Glance 2007: OECD Indicators, 2007.

6. K. Davis, C. Schoen, and K. Stremikis, The Commonwealth Fund, Mirror, Mirror on the Wall - How the Performance of the U.S. Health Care System Compares Internationally 2010 Update, June 2010, at 16, available at <http://www.commonwealthfund.org/ /media/Files/Publications/Fund $\% 20$ Report/2010/Jun/1400_Davis_Mirror_Mirror_on_the wall_2010.pdf $>$ (last visited July $\overline{7}, 2011$ ); $\bar{E}$. Nolte and C. M. McKee, "Measuring the Health of Nations: Updating an Earlier Analysis," Health Affairs 27, no. 1 (2008): 58-71.

7. The public health system is the "intersectoral system that comprises the government public-health agencies and various partners, including communities, the health care delivery system, employers and business, the media, and academia." Institute of Medicine, Committee on Public Health Strategies to Improve Health, For the Public's Health: The Role of Measurement in Action and Accountability (Washington, D.C.: National Academies Press, 2011): at 1, available at <http://books.nap.edu/ openbook.php?record_id $=13005 \&$ page $=R>$ (last visited July 12, 2011) (hereinafter cited as IOM Measurement); Institute of Medicine, Committee on Assuring the Health of the Public in the 21st Century, The Future of the Public's Health in the 21st Century (Washington, D.C.: National Academies Press, 2003): at 2, available at <http://www.nap.edu/openbook. php?isbn $=030908704 \mathrm{X}>$ (last visited July 12, 2011) (hereinafter cited as IOM 21st Century). An important responsibility of the governmental public health agencies is to promulgate laws and policies that regulate risks to the health and safety of the population. L. O. Gostin, Public Health Law: Poreer, Duty, Restraint (Berkeley: University of California Press, 2008): at 149. Some important federal public health agencies include the Department of Health and Human Services (and the departments therein, CDC, CMS, FDA, NIH) and the Department of Homeland Security (especially the Federal Emergency Management Administration). Id., at 157. The administrative agencies and the regulations and policies they develop are an important component of public health law. Public health law is defined as "the study of legal powers and duties of the state, in collabora- 
tion with its partners to ensure the conditions for people to be healthy, and of the limitations on the power of the state to constrain individual rights." $I d$., at 4 .

8. See IOM 21st Century, supra note 7, at 8-10; P. D. Jacobson and L. O. Gostin, "Restoring Health in Health Care Reform," JAMA 304, no. 1 (2010): $85-86$.

9. R. Saver, "Where's the Public Health," Concurring Opinions, available at $<$ www.concurringopinions.com/archives/category/ symposium-health-care-fragmentation $>$ (last visited June 21 , 2011); see discussion infra Part III (B)(1) (testimony of Dr. Richard Besser, Acting Director of the Centers for Disease Control and Prevention).

10. See IOM 21st Century, supra note 7, at 9.

11. See IOM Measurement, supra note 7 , at 4 .

12. "The governmental public health infrastructure was [deficient] because of political neglect and political pressure and public opinion that [often] overrode evidence." See IOM 21st Century, supra note 7 , at 3.

13. The report actually titles these items "areas of action and change." There is a separate section of the report entitled "Findings and Recommendations," which contains 34 more specific items. See IOM 21st Century, supra note 7, at 3, 4-17.

14. The need for development of a system of accountability for governmental and non-governmental actors that are responsible for and impact population health was reiterated in the IOM's 2010 report. See IOM Measurement, supra note 7, at 9- 10.

15. See IOM 21st Century, supra note 7 , at 4 .

16. See IOM Measurement, supra note 7 , at 2.

17. Id. This would also mean that the United States would better allocate resources between clinical and community-based prevention efforts. Thus we would not continue the disproportionate spending of $4 \%$ on prevention and $96 \%$ of health care spending on Medical Services. J. Levi, "Trust for America's Health," Handout, at Slide 5, October 8, 2008 (on file with the author); M. B. Barton, T. Miller, and S. L. Mercer, Handout, at Slide 3, November 12, 2008 (noting that of the 2.3 trillion spent on health care, " $5 \%$ goes to prevent disease, injury, and disability") (on file with the author); J. M. Lambrew, Hamilton Project, $A$ Wellness Trust to Prioritize Disease Prevention, April 2007 (1-3\% total health care expenditures spent on prevention (or $\$ 70 \mathrm{M}$ ) in 2007).

18. See Barton, Miller, and Mercer, Handout, November 12 , 2008.

19. J. Levi, Trust for America's Health, Handout, October 8, 2008. Trust for America's Health is a "nonpartisan, nonprofit organization dedicated to saving lives by protecting the health of every community and working to make disease prevention a national priority." Id., at 1. Trust for America's Health, Prevention for a Healthier America: Investments in Disease Prevention Yield Significant Savings, Stronger Communities, July 2008. The presentation was based upon a report jointly prepared by Trust for America's Health, the New York Academy of Medicine, the Prevention Institute, the Urban Institute, the California Endowment, and the Robert Woods Johnson Foundation. The report noted that a $\$ 10$ per person per year investment in "proven community-based prevention programs to increase physical activity and good nutrition and prevent smoking and other tobacco use" would save $\$ 16$ billion annually within 5 years.

20. This bill was first introduced in 2004. Healthy Lifestyles and Prevention America Act, S. 2558, 108th Cong. (2004); 150 Cong. Rec. S704701 (daily ed. June 18, 2004) (statement of Sen. Harkin). The titles of the bill convey that vision. In 2007, title I created a federal task force on childhood obesity; title II focused on creating healthier kids and schools; title III included initiatives creating healthier communities and workplaces; title IV focused on responsible marketing and consumer awareness; title $V$ provided reimbursement and coverage of preventive services; title VI created the Healthy Lifestyles and Prevention America Trust Fund; and title V focused on research. Healthy Lifestyles and Prevention America Act, S. 1342, 110th Cong. (2007).
21. Healthy Workforce Act of 2007, S.1753, 110th Cong. (2007).

22. Healthy Workforce Act of 2007, S.1753, 110th Cong. (2007). For a detailed analysis of the benefits of corporate wellness programs, recent legislative and presidential initiatives targeted to encourage their use, and recommendations on how to expand their use as part of health care reform to include integrative medicine, see G. R. Majette, "Healthcare Reform \& the Missing Voice of Complementary and Alternative Medicine," Houston Journal of Health Law E' Policy 10, no. 1 (2009): 35-61, at 51-61.

23. 21st Century Wellness Trust Act, S. 3674, 110th Cong. (2008) (hereinafter cited as 21st Century Wellness Trust Act). This bill was based upon a 2006 paper authored by Jeanne M. Lambrew and John D. Podesta entitled, "Promoting Prevention and Preempting Costs." J. M. Lambrew and J. D. Podesta, Center for American Progress, Promoting Prevention and Preempting Costs: A New Wellness Trust for the United States, October 5 , 2006.

24. Id. (21st Century Wellness Trust Act), at $\S 2$ (b).

25. Id., at $\$ 3$ (see Part S-Wellness Trust $\$ \$ 399 \mathrm{LL}, 399 \mathrm{NN}$ ). 26. Id., at $\$ 399 \mathrm{NN}(\mathrm{b})(\mathbf{1})-(3)$.

27. Id., at $\$ 399$ OO. The pooled resources would allow one entity to have direction over prevention activities to better coordinate and target resources to achieve the prevention priority goals established by the Trustees. The assessment on private insurance and self-insured employers would be equal to their estimated expenditures on prevention. Id., at $\$ 399$ OO (d).

28. M. Baucus, Senate Finance Committee, Call to Action Health Reform 2009, November 12, 2008 (hereinafter cited as Baucus Call to Action), available at <http://finance.senate.gov/ download $/$ ?id=916boea3-96dc-4c7a-bb35-241fa $822367 \mathrm{e}>$ (last visited July 12, 2011).

29. $I d$., at I.

30. Id., at 29. The elimination of co-payments would encourage people to get preventive services and hopefully lower the costs that chronic diseases would have on the federal public health programs. Currently, "96 cents of every Medicare dollar and 83 cents of every Medicaid dollar are used to treat chronic diseases." Id. See also Healthy Lifestyles and Prevention America Act, S. 1342, 110th Cong. (2007) (Title V focuses on coverage expansion and reimbursement for prevention services).

31. The benefit package would be based upon recommendations by the "U.S. Preventive Services Task Force, the Advisory Committee on Immunization Practices, National Institution for Health, Centers for Disease Control and Prevention, and the Institute of Medicine." See Baucus Call to Action, supra note 28 , at 30 .

32. Id. (Baucus Call to Action), at 29. The right choices card was a temporary measure to cover the uninsured until the insurance exchange became operational. Id.

33. Id., at 30; Healthy Workforce Act of 2007, S.1753, 110th Cong. (2007).

34. Id. (Baucus Call to Action), at 30. Healthy Lifestyles and Prevention America Act, S. 1342, 110th Cong. (2007) (Title III provides for Healthy Community Grants).

35. Id.; see 21st Century Wellness Trust Act, supra note 23. See also Healthy Lifestyles and Prevention America Act, S. 1342, 110th Cong. (2007) (Title VI creates the Healthy Lifestyles and Prevention American Trust Fund).

36. See Baucus Call to Action, supra note 28, at 30.

37. Because of his 2008 diagnosis with a malignant brain tumor, Senator Kennedy asked Senator Christopher Dodd, who was another HELP committee member, to be his Chief Deputy for health care reform. Senator Kennedy was a long-time advocate for comprehensive health care reform. E. M. Kennedy, "The Cause of My Life,' Inside the Fight for Universal Health Care," Nerwweek, July 18, 2009, available at <http://www.newsweek. com/2009/07/17/the-cause-of-my-life.html> (last visited July 12, 2011). Senator Kennedy was also a major player in securing most of the significant health care legislation enacted during his tenure of 46 years in the United States Senate. Id. It was no different during the most recent push for health care reform. Accordingly, Senator Kennedy and his staff were instrumental 
in securing the prevention, wellness, and public health provisions in the Senate health care reform proposals. Senators Ted Kennedy, Chris Dodd, and Tom Harkin, and their staffs ("team prevention") worked together to organize stakeholder meetings, draft language, and hold hearings.

38. T. Harkin, "Op-Ed Contributor: Shifting America from Sick Care to Genuine Wellness," Yahoo! News, available at $<$ http:// news.yahoo.com/s/ynews/ynews_ts408> (last visited June 21, 2011); 155 Cong. Rec. S10389-01 (daily ed. Oct. 14, 2009) (statement of Sen. Harkin).

39. On May 5, 2011, a search was conducted in the ProQuest Congressional database for health care reform hearings from 2008-2010 before the Ways and Means Committee of the House of Representatives, the Committee on Energy and Commerce, the House Education and Labor Committee, the Senate Committee on Health Education Labor and Pensions, and the Health Subcommittee of the Senate Finance Committee. Reports by Democratic leadership report many more hearings on congressional reform: House of Representative ("79 bipartisan hearings and mark-ups"), Senate Finance Committee (53 hearings), and Senate HELP Committee (" 47 bipartisan hearings"). Offices of Democratic Leadership, Democrats Carry Out Open, Transparent Health Reform Debate, March 19, 2010.

40. Prevention and Public Health: The Key to Transforming our Sickcare System: Hearing Before the Sen. Comm. on Health, Education, Labor and Pensions, 110th Cong. (2008) (herein after cited as Prevention Hearing) (witnesses Donald Wright, Principal Deputy Assistant Secretary for Health, U.S. Department of Health and Human Services; Jeffrey Levi, Executive Director, Trust for America's Health; and Kenneth E. Thorpe, Professor and Chair at the Rollins School of Public Health at Emory University).

41. Id., at 2 (written testimony of Donald Wright, Principal Deputy Assistant Secretary for Health, U.S. Department of Health and Human Services).

42. Id.

43. Id., at 5. Healthy People 2000 was released in 1990 . It had three purposes: (1) to improve the length and quality of life of Americans; (2) to eliminate disparities; and (3) to improve access to preventive health services. The Healthy People report identifies priority areas and objectives for each priority. The federal government then monitors progress on those priority areas. R. K. Thomas, Health Services Planning, 2nd ed. (New York: Kluwer Academic Publishers, 2003): at 30.

44. See Prevention Hearing, supra note 40, at 5.

45 . With respect to exercise and nutrition, the Department has created a Physical Activity Guideline for Americans and Dietary Guideline for Americans. With respect to clinical prevention and community prevention, the U.S. Preventive Services Task Force and the Task Force on Community Prevention working with the Agency for Healthcare Research and Quality develop recommendations for clinical prevention services and community preventive services. Id., at 6-7, 9. Recently, the CDC, AHRQ, and the National Business Group on Health collaborated in publishing a "Purchasers Guide to Clinical Preventive Services" to move the evidence of clinical prevention into benefit coverage design. Id., at 8 .

46. He discussed the activities of the CDC, NIH, FDA, CMS, Substance Abuse and Mental Services Administration (SAMSA), and Health Resources Services Administration (HRSA).

47. Id., at $12(\mathrm{CDC})$; Id., at $13(\mathrm{NIH})$

48. He also discussed other public health problems. First, he noted that the public health workforce needs to be strengthened. Second he noted that public health programs should be based on evidence and focus on quality. Third, he reiterated the need for the health care system to be designed to respond to public health emergencies. See Prevention Hearing, supra note 40 , at 1 (written testimony of Jeffrey Levi, Executive Director Trust for America's Health).

49. $I d$. , at 1.

50. Id. The ideas for this testimony are based upon a report published by Trust for America's Health, Blueprint for a Healthier
America: Modernizing the Federal Public Health System to Focus on Prevention and Preparedness. Trust for America's Health, Blueprint for a Healthier America: Modernizing the Federal Public Health System to Focus on Prevention and Preparedness, October 2008.

51. Id. (Prevention Hearing), at 4 (written testimony of Jeffrey Levi, Executive Director Trust for America's Health). He also asserted the need for a high level official at HHS with medical, scientific, and public health expertise to coordinate policy and activities for public health. $I d$., at 4.

52. Id., at 3. He recommended using a wellness trust such as the one proposed by Senator Hillary Clinton in S. 3764 and Congresswoman Matsui in H.R. 7287.

53. See Prevention Hearing, supra note 40, at 2 (written testimony of Kenneth E. Thorpe, Professor and Chair at the Rollins School of Public Health at Emory University).

54. Id., at 11 .

55. Id., at 13 .

56. Id., at 15 .

57. $I d$.

58. Id., at 16 .

59. Id.

60. See Majette, supra note 22, at note 80 ; Examining Principles of Integrative Health, Focusing on A Path to Healthcare Reform: Hearing Before the Sen. Comm. on Health, Education, Labor, and Pensions, 111th Cong. 387 (2009); Integrative Care: A Pathway to a Healthier Nation: Hearing before the Sen. Comm. on Health, Education, Labor, and Pensions, 111th Cong. 387 (2009) (hereinafter cited as Integrative Health Hearing). Integrative medicine takes the most effective treatments from conventional, complementary, or alternative medicine and makes them available to patients for a comprehensive and individualized treatment plan. Integrative Care: $A$ Pathroay to a Healthier Nation: Hearing Before the Sen. Comm. on Health, Education, Labor, and Pensions, 111th Cong. 387 (2009) (testimony of Sister Charlotte Rose, Practitioner and Professor Emeritus, Tai Sophia Institute ); D. L. Katz and A. Ali, Preventive Medicine, Integrative Medicine $\xi^{\circ}$ the Health of the Public, February 2009, at 6 (report commissioned for the IOM Summit on Integrative Medicine and the Health of the Public, February 2009); Majette, supra note 22, at 41.

61. See Integrative Health Hearing, supra note 60 (testimony of Cathy Baase, Global Director of Health Services, Dow Chemical Company).

62. Id. (testimony of Wayne Jonas, President, Samueli Institute).

63. Sen. Comm. on Health, Education, Labor \& Pensions, In Historic Vote, HELP Committee Approves the Affordable Health Choices Act, July 15, 2009 (on file with author).

64. Affordable Health Choices Act, 111th Cong. (2009) (bill draft on HELP website (labeled BAI09153.xmlo) (on file with the author).

65. Id., at $\$ \S 301,302$.

66. M. Baucus, Chairman's Mark America's Healthy Futures Act of 2009 , September 16, 2009 (on file with the author).

67. Chairman's Mark, Subtitle A - Medicare, at 69-70.

68. $I d$, at 71-72.

69. Chairman's Mark, Subtitle B - Medicaid, at 72-73.

70. Id., at 73 .

71. $I d$., at 74-75.

72. See discussion in Part II.

73. Making Health Care Work for American Families: The Role of Public Health: Hearing Before the H. Comm. on Energy and Commerce, 111th Cong. (2009), at 3 (written testimony of Richard E. Besser, Acting Director for the Centers for Disease Control \& Prevention, U.S. Department of Health and Human Services) (hereinafter cited as Making Health Care Work Hearing).

74. Id., at 2.

75. $I d$.

76. Id., at 12 .

77. Id. 
78. Id., at 9. See also American Reinvestment and Recovery Act, Pub. L. No. 111-5, Sec. 2 (Title VIII), 123 Stat. 115, 180-181 (2009).

79. See Making Health Care Work Hearing, supra note 73 , at 10 (written testimony of Richard E. Besser, Acting Director for the Centers for Disease Control \& Prevention, US. Department of Health and Human Services). For immunizations, a $\$ 300$ million investment was made; for health care-associated infections, a $\$ 50$ million investment was made to help states with this initiative; and $\$ 650$ million was invested in evidencebased clinical and community interventions to reduce chronic diseases. Id., at 9-10.

80. Id., at 4-7.

81. Id., at 3 .

82. Making Health Care Work Hearing, supra note 73, at 1 (testimony of Jonathan E. Fielding, Director and Health Office of the Task Force on Community Preventive Services (TFCPS) and Chair of the Secretary's Advisory Committee on National Health Promotion and Disease Prevention Objectives for 2020). Population health is delivered to a group or community. In contrast clinical care is delivered to one patient at a time. $I d$, at 2.

83. The work of the Community Prevention Guide began in 1996 "under the auspices of the CDC." The Task force has conducted over 200 reviews. Id., at 3. The Community Prevention Guide links to the Guide to Clinical Preventive Services by explaining how to better deliver the recommended clinical service to the target population effectively and efficiently. The Community Prevention Guide can for example "assess the effectiveness of ... media education,... patient reminders, professional reminders, use of financial incentives, and the organization and structure of care." Id., at 4. The target audience for the guide is organizations that "deliver population-based services like employers, schools, governmental public health agencies, health care systems, medical groups, community organizations, and policy makers." $I d$., at 3.

84. Id., at 4,5 .

85. Id., at 5. The goal is to move beyond passive distribution via mere publication, internet availability, and inclusion in a few grants. The goal is "to help the employers, communities,...public health departments...develop the skills to adopt and implement the recommendations." Id.

86. See Making Health Care Work Hearing, supra note 66, at 5 (written testimony of Jonathan E. Fielding, Director and Health Office of the Task Force on Community Preventive Services [TFCPS] and Chair of the Secretary's Advisory Committee on National Health Promotion and Disease Prevention Objectives for 2020).

87. Id., at 8 .

88. See discussion in Part III.A.2.

89. Id., at 4. There is an estimated $\$ 20$ billion per year shortfall. Currently the country spends approximately $\$ 35$ billion per year. The ARRA $\$ 650$ million funding was a one-time historic investment. $I d$.

90. Id., at 5.

91. Id., at 7. This organization would be housed in the CDC or the Agency for Healthcare Research and Quality. This organization would also have an accountability function to evaluate how well tax dollars were spent.

92. See Making Health Care Work Hearing, supra note 73, at 4 (testimony of David Satcher, 16th U.S. Surgeon Gen., and Director of the Satcher Health Leadership Institute at Morehouse School of Medicine, citing Volume 1 of Healthy People 2010); G. R. Wilensky and D. S. Satcher, "Don't Forget about the Social Determinants of Health," Health Affairs Web Exclusive (January 1, 2009): w194-w198, at 198.

93. Id. (Making Health Care Work Hearing), at 4 (testimony of David Satcher, 16th U.S. Surgeon Gen., and Director of the Satcher Health Leadership Institute at Morehouse School of Medicine, citing Volume 1 of Healthy People 2010); see also id. (Wilensky and Satcher), at w194, 198.

94. Id. (Making Health Care Work Hearing), at 4-5.
95. Id. (Making Health Care Work Hearing), at 7 (written testimony of David Satcher, 16th U.S. Surgeon Gen., and Director of the Satcher Health Leadership Institute at Morehouse School of Medicine).

96. Id., at 8 .

97. Id., at 7; see Wilensky and Satcher, supra note 92, at w198.

98. Id. (Making Health Care Work Hearing), at 9.

99. Id., at 1 (written testimony of Barbara Spivak, MD).

100. Id., at 2

101. $I d$.

102. Id., at 7 .

103. Id., at 7-8.

104. Health Reform in the 21st Century: A Conversation with Health and Human Services Secretary Kathleen Sebelius: Hearing Before the H. Comm. on Ways and Means, 111th Cong. (2009) (written testimony of Kathleen Sebelius, Secretary of the U.S. Department of Health and Human Services).

105. H.R. 3200, 111th Cong. (2009). H.R. 3200 was a comprehensive health care reform bill that served as the precursor to H.R. 3962 which ultimately passed in the House of Representatives on November 7, 2009.

106. H. Rep. No. 111-299 at 699-700 (2009).

107. H.R. 3200, 111th Cong. Sess. 1 (2009). The other subchapter is (6) Subtitle F - Core Public Health Infrastructure. Subtitle D - Prevention and Wellness Research directs the CDC and NIH to take into consideration the national strategy on prevention, recommendations of the Task Forces on Clinical and Community Prevention in awarding research grants and to support research on prevention and wellness. It also provides funding to the CDC to support research on community preventive service. Subtitle E creates a grant program at the CDC to fund evidence-based community prevention and wellness and requires that $50 \%$ of the funds be used to implement services to reduce disparities. Subtitle $\mathbf{F}$ creates a grant program at the CDC to improve core public health infrastructure and provides additional funds for the CDC to address unmet and emerging public health needs.

108. Professors Peter D. Jacobson and Lawrence O. Gostin, two leading public health law experts, noted that PPACA makes public health a national priority and innovates with respect to prevention and wellness. See Jacobson and Gostin, supra note 8. For an analysis of some of PPACA's prevention and wellness provisions from a leading preventive medicine physician, Miriam Alexander, see C. M. Preston and M. Alexander, "Prevention in the United States Affordable Care Act," Journal of Preventive Medicine and Public Health 43, no. 6 (2010): $455-458$

109. Patient Protection and Affordable Care Act, Pub. L. No. 111148, 124 Stat. 573 (2010) (hereinafter cited at PPACA), at $\$ \$ 4101,4104,4103,4107$, and 4108 .

110. Id. at $\$ \$ 4201,4205$, and 4207 .

111. $I d$., at $\$ \$ 4303,4306$, and 4305 .

112. Id., at $\$ 4001$ (a), (b), and (d)(1).

113. Exec. Order No. 13544 of June 10, 2010, 75 Fed. Reg. 33983 (June 16, 2010).

114. The members include the Secretaries of Health and Human Services, Agriculture, Education, Transportation, Labor, and Homeland Security, the Chairman of the Federal Trade Commission, the Administrator of the Environmental Protection Agency, the Director of the Office of National Drug Control Policy, the Director of the Domestic Policy Council, the Assistant Secretary for Indian Affairs, and the Chairman of the Corporation for National and Community Service. See PPACA, supra note 109, at \$ 4001 (c).

115. Creation of the strategy is a participatory process. The strategy must be created with the input of "relevant stakeholders." See PPACA, supra note 109 , at $\$ 4001$ (d)(2).

116. There are five categories of interventions: (1) creation of evidenced-based policy; (2) implementation of procedures that cause system change within organizations; (3) creation of social and physical environments that support healthy living; (4) use of communications and the media to raise health 
awareness; and (5) the design and delivery of programs in settings where they will get the most use. National Prevention, Health Promotion and Public Health Council, 2010 Annual Status Report, July 1, 2010, at 9 (hereinafter cited as 2010 Annual Status Report).

117. See PPACA, supra note 109 , at $\$ 4001$ (g).

118. The five leading canses of death in the United States are (1) heart disease, (2) cancers, (3) stroke, (4) chronic lower respiratory disease, and (5) unintentional injuries. Some of the core underlying causes of these deaths include tobacco use, poor nutrition, physical inactivity, and underage and excessive alcohol use. See 2010 Annual Status Report, supra note 116 , at 6-8.

119. The report acknowledges the "vast inequities" in the health system and notes that "specific action and metrics" should be used to "monitor and eliminate disparities" related to "race/ ethnicity, age, sex, gender, sexual orientation, geography, socioeconomic status, and disability status." Id., at 4.

120. Id., at 3-4.

121. Id., at 1 . Some other programs identified include (a) The First Lady's Let's Move Initiative (childhood obesity); (b) The Surgeon General's Vision for a Healthy and Fit Nation 2010; (c) Communities Putting Prevention to Work (grant funding from the American Recovery and Reinvestment Act); (d) Ending the Tobacco Epidemic: A Tobacco Control Strategic Action Plan for the United States; (e) Toward Zero Deaths: A National Strategy on Highway Safety; (f) The Safe Routes to School Program; and (g) the President's Food Safety Working Group. Id., at 1-2.

122. See PPACA, supra note 109 , at $\$ 4001$ (g); Exec. Order No. 13544 of June 10, 2010, 75 Fed. Reg. 33983 (June 16, 2010).

123. National Prevention, Health Promotion, and Public Health Council, Draft Framework National Prevention Strategy, April 4, 2011 at 1 (hereinafter cited as Draft Prevention Strat124. Id. egy Framework).

125. Id., at 2.

126. $I d$.

127. Id.

128. $I d$.

129. The broader priority is called "Cross-Cutting Priorities." Crosscutting priorities include healthy environments, prevention and public health capacity, and clinical preventive services. See Draft Prevention Strategy Framework, supra note 123, at 3.

130. Id., at 3 .

131. See PPACA, supra note 109 , at $\S 4001$ (d)(3).

132. The Advisory Group is appointed by the President. The group must be a diverse group of health care professionals with expertise in "worksite health promotion, community services, Preventive medicine, health coaching, public health education, geriatrics, and rehabilitation medicine." See PPACA, supra note 109, at $\$ 4001$ (f). On January 26, 2011, President Obama appointed 11 members to the council, and on April 8, 2011, he appointed two additional members. On April 11, Surgeon General Dr. Regina M. Benjamin appointed Dr. Jeffrey Levi as Chair of the advisory council. See HHS website, available at <http://www.healthcare.gov/center/councils/ nphpphc/index.html> (last visited June 21, 2011).

133. See PPACA, supra note 109 , at $\$ 4001$ (f)(3).

134. Id., at $\$ \$ 4001(\mathrm{~h})(1)$.

135. Id., at $\$ \$ 4001(\mathrm{~h})(3)$.

136. Id., at $\$ \$ 4001(\mathrm{~h})(4), 10401(\mathrm{a})$.

137. Id., at $\S \S 4001(\mathrm{~h})(6)-(7)$.

138. The continued availability of the full amount of the appropriation is theoretically at risk. Three attempts have been made in the House of Representatives to defund the prevention fund. The Johanns amendment would have drastically cut the fund. This amendment was defeated in September 2010. Johanns Amendment, section 4273 (a). The current and ongoing attack is through the Pitts proposal. This proposal would eliminate all mandatory funding in PPACA. Setting Fiscal Priorities in Health Care Funding: Hearing Before the H. Comm. on Energy and Commerce, 112th Cong. (2011) (March 7, 2011 Internal Memorandum of the Majority Staff to the Subcommittee on Health). On April 13, the House of Representatives passed H.R. 1217 which would repeal the Prevention and Public Health Fund. The White House expressed opposition to the bill and continued support for the fund. The measure is also unlikely to pass in the democratically controlled Senate. "House Repeals Affordable Care Act's Prevention and Public Health Fund," Health Lawyers Weekly, vol. IX, no. 15 (April 15, 2011).

139. See PPACA, supra note 109 , at $\$ 4002$ (a).

140. Id., at $\$ 4002$ (a)-(b).

141. PPACA merely authorizes the Prevention Council to make recommendations and submit reports to the President and Congress. See discussion in Parts V.A; see PPACA, supra note 109, at $\$ \S 4001,4002$.

142. There is a debate about whether investments in prevention will produce cost savings. Many of the witnesses that testified at the hearings discussed in this paper asserted that there will be cost savings: Dr. Jeffrey Levi with Trust for America's Health, Professor Kenneth Thorpe from the School of Public Health at Emory, Dr. Richard Besser, the Acting Director of the CDC, and Dr. Wayne Jonas, President of Samueli. Professor Goetzel and Thorpe wrote articles showing a financial benefit to prevention. R. Z. Goetzel, "The Wrong Debate: Prevention or Treatment Services to Save Money?: Instead of Debating Whether or Not Prevention or Treatment Saves Money, We Should Determine the Most Cost-Effective Ways to Improve Population Health," Health Affairs 28, no. 1 (2009): 37-41. K. E. Thorpe, "The Rise in Health Care Spending and What to Do about It," Health Affairs 24, no. 6 (2005): 1436-1445. Economics professor Louise Russell provides an analysis of reasons why prevention might not produce cost savings. L. B. Russell, "Preventing Chronic Disease: An Important Investment, but Don't Count on Cost Savings; An Overwhelming Percentage of Preventive Interventions Add More to Medical Costs Than They Save," Health Affairs 24, no. 1 (2009): 42-47.

143. U.N. Economic and Social Council, Committee on Economic, Social, and Cultural Rights, Substantive Issues Arising in the Implementation of the International Covenant on Economic, Social and Cultural Rights, General Comment No. 14 I 43 (f), 53 U.N. Doc. E/C.12/2000/4 (August 11, 2000) (hereinafter cited as Committee on Economic, Social, and Cultural Rights). The United States does not have an international obligation to protect the right to health because it has not ratified the most seminal treaty on the right to health, the International Covenant on Economic, Social, and Cultural Rights. International Covenant on Economic, Social, and Cultural Rights, at art. 12 (entered into force January 3, 1976). For a more in-depth analysis of how the Patient Protection Affordable Care Act creates a framework to protect the right to health, see G. R. Majette, "Coherency within the Patient Protection and Affordable Care Act (PPACA): A Framework to Create a Health Care System that Protects the Human Right to Health" (unpublished manuscript on file with the author).

144. U.N. Economic and Social Council, Committee on Economic, Social, and Cultural Rights, Substantive Issues Arising in the Implementation of the International Covenant on Economic, Social and Cultural Rights, General Comment No. 14 153 , U.N. Doc. E/C.12/2000/4 (August 11, 2000).

145. See PPACA, supra note 109 , at $\$ 4001$ (d)(3).

146. See discussion in Part II.

147. See IOM 21st Century, supra note 7 , at 4 . Accountability is a requirement for creation of an effective comprehensive plan to create and strengthen a health system under the core obligations that apply to all treaty parties. See Committee on Economic, Social, and Cultural Rights, supra note 143, at 56-57.

148. See PPACA, supra note 109 , at $\$ 4001$ (i).

149. H. Rep. No. 111-299 at 326 (2009).

150. Id., at 700 . 